\title{
Kewenangan Jaksa Agung Dalam Mengesampingkan Perkara Demi Kepentingan Umum
}

\author{
Kiki Astuti Wulandary Sutin \\ Magister Ilmu Hukum, Universitas Muslim Indonesia \\ Koresponden, Email: kikiyastuty21@gmail.com
}

\begin{abstract}
ABSTRAK
Penelitian ini bertujuan; Pertama mengetahui penerapan pengesampingan perkara dalam memenuhi adanya kepentingan umum, dan Kedua mengkaji dampak yang ditimbulkan dengan tidak adanya instrumen hukum untuk melakukan perlawanan terhadap keputusan pengesampingkan perkara demi kepentingan umum. Penelitian ini merupakan tipe penelitian normative dengan menggunakan pendekatan undang-undang, pendekatan kasus, pendekatan perbandingan, dan pendekatan konseptual. Hasil penelitian ini menunjukkan: Pertama Pengesampingan perkara terhadap perkara Abraham Samad dan Bambang Widjojanto dengan pertimbangan Jaksa Agung belum menunjukkan terganggunya kepentingan umum secara nyata; Kedua Tidak ditemukan adanya mekanisme untuk melakukan perlawanan atau upaya hukum terhadap keputusan pengesampingan perkara oleh Jaksa Agung sebagai bentuk kebebasan kebijaksanaan (beleidvrijheid) menimbulkan dampak yakni, keputusan pengesampingan perkara oleh Jaksa Agung bersifat final dan mengikat (final and binding),tidak mengakomodir hak-hak korban kejahatan sesuai prinsip perlakuan yang sama di hadapan hukum, dan kewenangan tersebut rawan terhadap penyalahgunaan kekuasaan.
\end{abstract}

Kata Kunci: Kewenangan; Jaksa; Perkara; Kepentingan Umum

\section{ABSTRACT}

The study aims to : (1) describe the public interest that becomes the basis of a general attorney in dismissing a case; (2) explain the implementation of dismissing a case to fulfill the public interest reason; and (3) analyze the impact caused by the absence of law instrumen againts the decision of dismissing a case for public interest. This research was a normative study usinglegal approach, case approach, comparative approach, and conceptual approach. It was conducted atthe Provincial Attorney General's Office of South Sulawesi. The results show that:(1) In the dismissing of a case, public interest indicates the existence of state's interest and community interest. This is in line with the explanation of article 35 letter c of the Act Number16 of 2004 that have to. The scope is broadand there is no standard in defining the public interest. Therefore, it needs to be considered within the context of state's constitutional principle according to the Preamble of 1945 Constitution. (2) The dismissing of the case of Abraham Samad and Bambang Widjojanto with the consideration of Attorney General have not indicatedthe disturbance of public interest. (3) There is no anymechanism to appealagaints the general attorney's decision to dismiss a case as a form of wisdom (beleidvrijheid), which caused some impacts namely the decision of general attorney to dismiss a case is final and binding, does not accommodate the rights of victims according to the principle of equality before the law, and vulnerable to abuse of power.

Keywords: Authority; Prosecutor; Case; Public interest 


\section{PENDAHULUAN}

Penuntutan perkara pidana dikenal adanya dua asas yang berlakuyaitu asas legalitas dan asas oportunitas (Adiatiawarman, 2017). Kedua asas tersebut berada dalam posisiyang saling berlawanan, di satu pihak asas legalitas menghendaki dilakukannyapenuntutan terhadap semua perkara ke pengadilan, tanpa terkecuali. Sedangkan disisi lain asas oportunitas memberikan peluang bagi penuntut umum untuk tidakmelakukan penuntutan perkara pidana di pengadilan (Yudha, 2020).

Terdapat beberapa negara yang menerima asas legalitas sebagai keharusan menuntut pidana (Yuherman, 2012). Sebaliknya di Prancis, Belgia, Belanda dan Indonesia diterapkan asas oportunitas yang menentukan bahwa pemerintah berwenang untuk tidak berkewajiban menurut undang-undang untuk menuntut semua perbuatan pidana. Di Indonesia sendiri, KUHAP cenderung untuk mengutamakan prinsip legalitas sedangkan prinsip oportunitas hanya merupakan pengecualian yang dapat dipergunakan secara terbatas. Sejalan dengan itu KUHAP tidak mengatur tentang pengesampingan perkara akan tetapi mengenalnya. Pengaturan pengesampingan perkara sendiri terdapat di dalam Undang-Undang Kejaksaan (Hisamudin, 2016).

Pelaksanaan asas oportunitas di Indonesia, kewenangan tersebut dimiliki oleh Jaksa Agung Republik Indonesia. Dalam hal ini kewenangan tersebut dapat mengabaikan penuntutan dalam arti bahwa Jaksa Agung dapat mengesampingkan penuntutan perkara pidana demi kepentingan umum (Chalil, 2016). Ketentuan pengesampingan perkara tersebut diakomodir dalam Undang-Undang Nomor 16 Tahun 2004 Tentang Kejaksaan Pasal 35 huruf c : "Jaksa Agung mempunyai tugas dan wewenang : ... c. Mengesampingkan perkara demi kepentingan umum“.

Kejaksaan Republik Indonesia dalam hal ini dipimpin secara fungsional oleh Jaksa Agung memiliki kewenangan tersebut sepenuhnya. Hal ini tentu berbeda dengan kewenangan penuntut umum untuk menghentikan penuntutan demi hukum, berdasarkan UndangUndang No. 16 Tahun 2004 tentang Kejaksaan Republik Indonesia Pasal 35 (c) yang berbunyi "Jaksa Agung mempunyai tugas dan wewenang mengesampingkan perkara demi kepentingan umum" (Marom \& Suryanto, 2020). Hal ini juga mengindikasikan pelaksanaan asas oportunitashanya dapat diberikan oleh Jaksa Agung, dengan kewenangan tersebut Jaksa Agung dapat mengintervensi proses hukum dalam tahapan penuntutan terhadap perkaraperkara pidana.

Legalitas wewenang Jaksa Agung untuk mengesampingkan perkara pidana menurut kepentingan umum sebenarnya bukanlah sesuatu yang baru lagi. Sebelumnya UndangUndang tentang Kejaksaan telah mengatur kewenangan ini pada Undang-Undang No. 15 Tahun 1961 tentang Ketentuan-Ketentuan Pokok Kejaksaan Republik Indonesia bahwa "Jaksa Agung dapat menyampingkan suatu perkara berdasarkan kepentingan umum” (Nugraha, 2020). Kemudian Undang-Undang tersebut dicabut dan diganti dengan Undang-Undang Nomor 5 Tahun 1991 tentang Kejaksaan Republik Indonesia yang kemudian dicabut dan diganti dengan Undang-Undang Nomor 16 Tahun 2004 tentang Kejaksaan Republik Indonesia. Kewenangan pengesampingan perkara tetap melekat di Jaksa Agung dari masa ke masa peraturan perundangan tentang Kejaksaan.

Kejaksaan mempunyai kewenangan selain melakukan penuntutan pidana dan kewenangan lain menurut undang-undang, di sisi lain terdapat juga wewenang untuk mengesampingkan perkara pidana yang dikaitkan dengan pelaksanaan asas oportunitas (Iqbal, 2018). Asas 
oportunitas sendiri bertolak belakang dengan asas legalitas dalam konteks penuntutan perkara (Basalama, 2017). Disisi lain asas legalitas memberi kewenangan kepada penuntut umum untuk melakukan penuntutan tanpa terkecuali sesuai prosedur hukum yang berlaku, sedangkan asas oportunitas merupakan asas yang melandaskan penuntut umum untuk mempunyai kewenangan untuk tidak menuntut suatu perkara di muka sidang pengadilan dengan alasan demi kepentingan umumsehingga memberikan kesempatan untuk tidak melakukan penuntutan (Suhariyanto, 2015).

Pada perkembangannya, penerapan untuk mengesampingkan perkara pidana menurut kepentingan umum bukanlah suatu hal yang sering dilakukan. Dimasa setelah reformasi sendiri seponering diberikan terhadap perkara yang menjerat pimpinan Komisi Pemberantasan Korupsi. Di tahun 2011, Jaksa Agung Basrief Arief mengeluarkan seponering atau pengesampingkan perkara demi kepentingan umum terhadap pimpinan Komisi Pemberantasan Korupsi (KPK) yaitu Chandra Martha Hamzah dan Bibit Samad Rianto, melalui Tap 001/A/JA/2011 dan Tap 002/A/JA/2011 mengambil keputusan untuk menyampingkan kasus tersebut dengan alasan untuk kepentingan umum. Hal sama pun terjadi terhadap pimpinan KPK baru-baru ini yaitu Abraham Samad dan Bambang Widjojanto yang terlibat perkara pidana dan perkaranya dikesampingkan di pertengahan 2015.

Pengesampingan perkara pidana yang terjadi belakangan ini juga menimbulkan perdebatan di publik terkait keputusan dan pertimbangan Jaksa Agung (Rahman, 2010). Terutama dua kasus terakhir yang dikesampingkan Jaksa Agung demi kepentingan umum diberikan kepada pimpinan KPK. Dalam kasus Abraham Samad dan Bambang Widjojanto yang diseponering, Jaksa Agung berpendapat bahwa kepentingan pemberantasan korupsi merupakan kepentingan umum. Ada 3 alasan pertimbangan deponering, alasan tersebut adalah filosofis, sosiologis dan yuridis. Alasan filosofis terjadinya kegaduhan publik karena terganggunya harmonisasi antar-institusi penegak hukum. Sehingga hukum tidak dapat terwujud secara maksimal. Alasan sosiologisnya adalah karena terganggunya pemberantasan korupsi sebab tersangka adalah tokoh dan aktivis yang diakui luas oleh masyarakat. Sementara alasan yuridis, yakni dalam rangka untuk mewujudkan kepastian hukum.

Berbagai isu terkait mengenai status tersangka, mekanisme pengeluarannya, dan yang paling utama mengenai frasa “demi kepentingan umum" menjadi polemikdalam pasal pengesampingan perkara demi kepentingan umum tersebut. Lebih lanjut mengenai frasa kepentingan umum, dijelaskan sesuai Pasal 35 huruf c Undang-Undang No. 16 Tahun 2004 bahwa:

“Yang dimaksud dengan 'kepentingan umum' adalah kepentingan bangsa dan Negara dan/atau kepentingan masyarakat. mengesampingkan sebagaimana dimaksud dalam ketentuan ini merupakan pelaksanaan asas oportunitas, yang hanya dapat dilakukan oleh Jaksa Agung setelah memperhatikan saran dan pendapat dari badan-badan kekuasaan Negara yang mempunyai hubungan dengan masalah tersebut"

Penjelasan terkait klausula "kepentingan bangsa dan negara dan/atau kepentingan masyarakat luas" tidak dijelaskan secara eksplisit dan cakupan yang luas dalam memaknai kepentingan tersebut sehingga dapat menjadi ruang bagi Jaksa Agung untuk rawan menyalahgunakan kewenangan tersebut. Sekaligus juga menunjukkan tidak adanya kepastian hukum dalam pasal tersebut terlebih lagi dalam pelaksanaannya.

Semakin kaburnya pelaksanaan asas oportunitas ini dengan memperhatikan pengaruh Kejaksaan dalam menerima intervensi politis dari lembaga lain dapat dilihat pada penjelasan 
Pasal 35 huruf c. Dalam pasal tersebut ada frasa "Setelah memperhatikan saran dan pendapat dari badan-badan kekuasaan negara yang mempunyai hubungan dengan masalah tersebut". Lalu kemudian menjadi permasalahan relevansi hubungan lembaga negara dengan suatu perkara hukum. Bagaimana mengikatnya saran dan pendapat tersebut dalammengintervensi kewenangan Jaksa Agung. Hal ini sekali lagi seakan-akan meniadakan kepastian hukum dan peran Kejaksaan sendiri sebagai institusi penegak hukum dalam memberikan seponering yang seharusnya berdasarkan kepentingan umum dan bebas dari intervensi politis.

Mengamati uraian tersebut diatas, penulis kemudian tertarik untuk mengangkat permasalahan terkait pengesampingan perkara demi kepentingan umum sebagai penelitian tesis karena berbagai isu dan polemik yang ada dimasyarakat. Hal ini ditinjau bahwa terhadap klausula demi kepentingan umum tidak memiliki parameter yang spesifik dan tidak dijelaskan secara eksplisit dalam undang-undang dan penjelasannya. Hal ini cenderung menimbulkan multitafsiryang berindikasi rawan mengakibatkan kesewenang-wenangan dan meniadakan kepastian hukum. Diangkatnya judul tersebut agar dapat dilakukan penelitian lebih lanjut untuk memperoleh pemahaman terhadap asas oportunitas khususnya pengesampingan perkara oleh Jaksa Agung. Hal ini juga terkait dalam memaknai kepentingan umum dan kriteria-kriteria kepentingan umum

\section{METODE PENELITIAN}

Kajian ilmu hukum digunakan untuk menjawab pertanyaan dan persoalan dalam penelitian ini ialah penelitian hukum normatif. Penelitian hukum normatif adalahpenelitian hukum yang meletakkan hukum sebagai sebuah bangunan sistem norma yang meliputi asas-asas, norma, kaidah dari peraturan perundang-undangan, putusan pengadilan, dan doktrin. Adapun penelitian normatif dilakukan dengan mengumpulkan dan menganalisis data sekunder (bahan-bahan kepustakaan ilmu hukum) yang terdiri dari Bahan hukum primer yaitu Undang-Undang Dasar 1945, Kitab Undang-Undang Hukum Acara Pidana, Perundangundangan yang terkait seperti Undang-Undang No. 16 Tahun 2004 tentang Kejaksaan Republik Indonesia, Yurisprudensi, dan Surat Ketetapan Mengesampingkan Perkara Demi Kepentingan Umum, dan Bahan hukum sekunder yaitu, bahan hukum yang dapat membantu menganalisa, memahami, dan menjelaskan bahan hukum primer, seperti teori hukum, buku, jurnal ilmiah, artikel, tesis, makalah, penelusuran internet, surat kabar dan seperti kamus. Untuk menunjang penelitian normatif yang mengkaji bahan-bahan hukum yang diperoleh, makadilakukan wawancara kepada para informan yang dapat menjawab permasalahan dalam penelitian.

\section{PEMBAHASAN}

\section{A. Penerapan Pengesampingan Perkara Dalam Memenuhi Adanya Kepentingan Umum}

\section{Analisis Kasus yang Dikesampingkan}

Keputusan Jaksa Agung dalam mengesampingkan suatu perkara sering menjadi perdebatan dikalangan publik. Tidak sedikit pihak yang tidak setuju saat kewenangan tersebut dilakukan untuk mengesampingkan suatu perkara. Seperti misalnya ketika baru-baru ini kewenangan Jaksa Agung itu dilakukan terhadap perkara dua pimpinan KPK yaitu Abraham Samad dan Bambang Widjojanto. Banyak pihak yang mengkritisi keputusan Jaksa Agung tersebut, 
bahkan banyak pihak yang melakukan suatu upaya hukum melalui gugatan ke Peradilan Tata Usaha Negara dan mengajukan permohonan praperadilan. Disadari bahwa pertimbangan Jaksa Agung dalam mengesampingkan suatu perkara terkadang bagi banyak pihak belum dapat dipahami tentang alasan adanya kepentingan umum.

Penulis ingin membahas lebih lanjut pertimbangan Jaksa Agung dalam mengesampingkan kasus Abraham Samad dan Bambang Widjojanto. Dibahasnya perkara ini untuk menganalisis lebih lanjut urgensi dan pertimbangan kepentingan umum perkara tersebut untuk dikesampingkan. Seperti yang telah dibahas sebelumnya, ada tiga pertimbangan yang dinilai oleh Jaksa Agung sehingga menganggap perkara tersebut layak untuk dikesampingkan demi kepentingan umum yaitu alasan filosofis, sosiologis dan yuridis.

Bambang Widjojanto disangkakan dengan pasal 242 ayat (1) juncto pasal 55 KUHP tentang menyuruh saksi untuk memberikan keterangan palsu di depan sidang pengadilan di Mahkamah Konstitusi. Dalam hal ini kasus sengketa pilkada di Kotawaringin Barat, Kalimantan Tengah pada 2010. Adapun Bambang Widjojanto terancam hukuman pidana sekitar 7 tahun penjara. Sementara Abraham Samad didakwa telah melakukan pemalsuan dokumen, Abraham Samad dijerat dengan Pasal 263 ayat (1) atau Pasal 264 ayat (1) juncto Pasal 55 ayat (1) KUHP subsider Pasal 266 ayat (1) juncto Pasal 55 ayat (1) KUHP atau Pasal 83, 94, 97 Undang-Undang Nomor 24 tentang Administrasi Kependudukan.Pada 31 Agustus 2015 Berkas Abraham Samad dalam dugaan pemalsuan dokumen dinyatakan sudah lengkap atau P21 di Kejaksaan Tinggi Sulawesi Selatan.

Lebih lanjut terdapat pendapat Adi Palebangan (Kasi Oharda Kejati Sulsel) terkait dengan pengesampingan perkara Abraham Samad dan Bambang Widjojanto "Pengesampingan perkara yang diberikan kepada pimpinan KPK yakni Abraham Samad dan Bambang Widjojanto memiliki urgensi kepentingan umum dengan melihat situasi pelemahan institusi KPK pada saat itu. SehinggaJaksa Agung melalui kewenangannya untuk mendeponir perkara tersebut sebagai bentuk penguatan KPK agar upaya pmberantasan korupsi dapat tetap berjalan."

Hal ini juga sejalan dengan pendapat Irma Ariani (Jaksa Pidsus Kejati Sulsel)

"Bahwa kebijakan mengeluarkan deponering haruslah mempertimbangkan baik itu asas keadilan, asas kepastian hukum, asas manfaat atau asas kepentingan umum. Pemberian deponering dalam konteks kepentingan umum untuk kasus AS-BW diberikan dengan pertimbangan kadar kesalahannya terhadap perkara yang dilakukan tidak sebanding dengan jasanya kepada negara sebagai figur dalam memberantas korupsi. Untuk mengukur kadar kesalahan perbuatannya dapat dilihat melalui kerugian yang diperoleh negara atau masyarakat luas, sementara dalam kasus tersebut tidak ada masyarakat yang dirugikan atau menjadi korban dari perbuatannya.”

Akan tetapi terdapat juga berbagai pandangan dari ahli hukum pidana yang tidak setuju dengan keputusan Jaksa Agung dalam mengesampingkan perkara Abraham Samad dan Bambang Widjojanto.Misalnya pendapat Romli Atmasasmita

"Dalam konteks seponering oleh Jaksa Agung RI kepada Abraham Samad dan Bambang Widjojanto telah diterapkan secara keliru karena dua hal. Pertama, tempus dan locus delicti terkait tindak pidana Abraham Samad dan Bambang Widjojanto terjadi ketika keduanya belum menjabat sebagai pimpinan KPK. Kedua, mantan pimpinan KPK tersebut hanya orang perorangan semata-mata dalam melaksanakan tugas profesinya. Merujuk pada locus dan 
tempus delicti tersebut sejujurnya harus diakui bahwa tidak ada relevansi dan urgensi pemberian seponering. Pemberian seponering tersebut oleh Jaksa Agung tidak memiliki nilai pembelajaran hukum kecuali terkesan perlakuan hukum yang bersifat diskriminatif dengan menggunakan alasan demi kepentingan umum."(Putusan Mahkamah Konstitusi, 2016;16).

Senada dengan itu Mudzakkir memberikan pandangan:

"Kalau perkara Abraham Samad dan Bambang Widjojanto dikesampingkan dengan alasan kedua mantan pimpinan KPK tersebut dikenal luas sebagai tokoh dan figur yang memiliki komitmen dalam pemberantasan korupsi. Kalau itu demi kepentingan negara dan masyarakat luas, artinya aparat penegak hukum harus dikesampingkan perkaranya semua. Berarti seluruh aktivis anti korupsi, penyidik, jaksa, komisioner KPK, kepolisian, termasuk juga Jaksa Agung bisa kebal hukum.Hal ini terjadi karena ketidakjelasan parameter "kepentingan umum"dalam penggunaan kewenangan seponering, yang tentunya akan membangun atmosfer yang tidak baik dalam dunia penegakan. Semestinya jika Jaksa Agung diberikan kewenangan berdasarkan UU Kejaksaan, wewenang itu harus ada parameter penggunaannya."

Disisi lain Indriyanto Seno Aji yang juga merupakan mantan komisioner KPK memberikan pandangan berbeda yakni:

"Pertama ada kepentingan negara dan bangsa yang lebih luas dibanding pengajuan ASBW ke hadapan sidang, yaitu terganggunya program negara dalam pemberantasan korupsi. Kedua, yaitu membangun komunikasi kelembagaan penegak hukum bagi pemberantasan korupsi, bukan sebaliknya yang justru menciptakan stigma kelembagaan penegak hukum"

Selanjutnya akan dibahas mengenai pertimbangan Jaksa Agung dalam mengesampingkan perkara tersebut serta kelayakan alasan-alasan tersebut. Pertama, adanya alasan filosofis yaitu terjadinya kegaduhan publik karena terganggunya harmonisasi antar-institusi penegak hukum. Seperti kronologis yang dibahas sebelumnya, perkara ini tidak lepas dari konflik tersirat antar institusi Polri dan KPK. Bermula dengan pencalonan Budi Gunawan oleh Presiden Joko Widodosebagai kandidat tunggal Kapolri. Komisi Pemberantasan Korupsi (KPK) kemudian mengumumkan Budi Gunawan sebagai tersangka korupsi saat ia menjabat Kepala Biro Pembinaan Karier Deputi Sumber Daya Manusia Polri dan jabatan lainnya di kepolisian. Selepas ditetapkannya Budi Gunawan sebagai tersangka, dua pimpinan KPK yakni Abraham Samad dan Bambang Widjojanto terjerat perkara hukum. Dapat dirasakan perselisihan yang terjadi antar dua institusi ini dimana pejabat dari masing institusi terjerat perkara hukum. Isu kriminalisasi mencuat terutama terhadap perkara yang menjerat dua pimpinan KPK tersebut.

Dapat dipahami perkara yang menjerat baik Budi Gunawan maupun Abraham Samad dan Bambang Widjojanto merupakan sumbu yang membuat tidak harmonisnya dua institusi ini. Akan tetapi, perkara hukum yang menjerat pejabat kedua institusi ini tidak lebih sebagai masalah hukum biasa saja yang tentunya dapat diselesaikan sesuai koridor hukum yang berlaku. Hal ini ditinjau dari upaya praperadilan yang diajukan oleh Budi Gunawan terhadap status tersangka yang ditetapkan oleh KPK. Pada akhirnya pengadilan memutuskan penetapan tersangka tersebut tidak sah, sekalipun muncul kontroversi terhadap putusan tersebut. Namun seyogyanya, isu kriminalisasi yang melanda dua pimpinan KPK tersebut dapat juga diselesaikan melalui proses peradilan tanpa adanya privildge tertentu. Sehingga menurut hemat penulis, tidak harmonisasnya dua institusi Polri-KPK akibat proses hukum kepada pihak-pihak dari masing-masing institusi belum mencapai tahap yang memprihatinkan. Dalam artian proses hukum di Pengadilan menjadi opsi yang tepat 
penyelesaian perkara hukum. Sehingga alasan seponering tersebut dirasa belum layak untuk menjadi pertimbangan dalam pengesampingan perkara. Bahkan yang muncul hanyalah perlakuan yang berbeda dan istimewa terhadap perkara yang menjerat dua pimpinan KPK tersebut.

Kedua, adanya alasan sosiologis yakni karena terganggunya pemberantasan korupsi sebab tersangka adalah tokoh dan aktivis yang diakui luas oleh masyarakat. Hal ini tentu terkait dengan kapasitas Abraham Samad dan Bambang Widjojanto sebagai pimpinan KPK. Terlibatnya dua pimpinan KPK tersebut dalam suatu perkara hukum dianggap dapat menganggu upaya pemberantasan korupsi. Harus diakui KPK telah menjadi lokomotif dalam upaya pemberantasan korupsi bersama Polri dan Kejaksaan. Namun institusi Polri dan Kejaksaan memiliki kedudukan yang sama dengan KPK sebagai institusi penegak hukum dalam memberantas korupsi. Terkait dengan kedudukan Abraham Samad dan Bambang Widjojanto sebagai pimpinan KPK, tentu muncul kekhawatiran dari publik akan terhambatnya kinerja KPK.

Merujuk pada Pasal 32 ayat 2 Undang-Undang No. 30 Tahun 2002 tentang KPK disebutkan jika pimpinan KPK menjadi tersangka maka harus diberhentikan sementara yang diputuskan oleh Presiden. Namun. sebelum adanya putusan pemberhentian sementara tersebut, kedua pimpinan KPK ini telah mengundurkan diri setelah ditetapkan jadi tersangka. Akan sulit pastinya bagi pejabat fungsional tertentu untuk menjalankan tugasnya secara maksimal sementara harus menjalani proses hukum. Dalam kondisi tersebut tentu dapat menghambat kinerja KPK untuk memberantas korupsi. Akan tetapi, Abraham Samad dan Bambang Widjojanto telah mengundurkan diri sehingga statusnya tidak lagi sebagai pimpinan KPK. Dan terhadap posisi pimpinan yang kosong tersebut saat itu telah digantikan oleh Indriyanto Seno Aji dan Taufiqurrahman Ruki sebagai pelaksana tugas sementara pimpinan KPK. Sehingga situasi internal KPK yang membutuhkan lima pimpinan dapat berjalan sebagaimana mestinya. Menurut hemat penulis, ditinjau dari keadaan KPK saat itu sepertinya tidak begitu menunjukkan adanya gangguan pemberantasan korupsi.

Deponering perkara, hanya bisa dilakukan kalau ada kepentingan bangsa dan negara yang lebih besar (Utoyo, 2016). Dalam kasus ini tidak ada kepentingan negara yang lebih besar yang bisa mengesampingkan kasus Samad dan Bambang Widjojanto. Hal ini sedikit berbeda dengan kasus Chandra Hamzah dan Bibit Samad Rianto, lasus Chandra dan Bibit bisa dideponering karena saat itu mereka masih menjabat. Berbeda dengan Samad dan Bambang yang sejak dikeluarkannya perpu pemberhentian sudah tidak menjabat dan oleh karenanya tidak ada lagi kepentingan negara dalam hal ini lembaga KPK.”

Ketiga, adanya alasan yuridis yakni dalam rangka untuk mewujudkan kepastian hukum. Menurut penulis, kepastian hukum hanya dapat diperoleh melalui proses peradilan sampai keluarnya putusan yang inkracht. Bukan melalui penetapan pengesampingan perkara yang menunjukkan bahwa perkara pidana tersebut memiliki bukti yang cukup dan layak untuk dilimpahkan ke pengadilan. Akan tetapi proses hukum tersebut tidak dilanjutkan dan dikesampingkan oleh Jaksa Agung karena adanya kepentingan umum. Sehingga penetapan pengesampingan perkara tersebut hanya memberikan kepastian hukum kepada tersangka bukan kepada korban tindak pidana. Oleh karenanya, tidak tepat untuk mengganggap pengesampingan perkara tersebut sebagai upaya untuk mewujudkan kepastian hukum dalam proses beracara pidana. 
Dari analisis ketiga alasan tersebutserta pendapat para pejabat di Kejaksaan dan ahli hukum. Maka keputusan untuk mengesampingkan perkara terhadap Abraham Samad dan Bambang Widjojanto belum menunjukkan terganggunya kepentingan umum secara nyata yakni kepentingan negara dan/atau kepentingan masyarakat luas. Oleh karenanya, terhadap keputusan tersebut banyak mendapatkan kritikan dari publik terkait urgensi dan pertimbangannya. Beberapa pihak kemudian merasa dirugikan dengan ditetapkannya pengesampingan tersebut yang menganggap sebagai bentuk ketidakadilan. Pihak-pihak yang merasa dirugikan tersebut melakukan permohonan praperadilan, diantaranya diajukan oleh tim hukum dari Suryadharma Ali dan O.C Kaligis yang melakukan permohonan tersebut. Seperti yang diketahui O.C Kaligis dan Suryadharma Ali merupakan terpidana perkara korupsi yang dijerat oleh KPK.

Pihak-pihak yang akan melakukan gugatan terhadap keputusan pengesampingan perkara terhadap Abraham Samad dan Bambang Widjojanto juga dilakukan oleh berbagai LSM. Mereka menggugat keputusan Jaksa Agung mendeponir kasus Abraham dan Bambang melalui tiga jalur, yakni praperadilan, PTUN, dan MK. Dalam bab selanjutnya akan dianalisis lebih lanjut terkait mekanisme hukum untuk menggugat keputusan pengesampingan perkara tersebut melalui praperadilan, PTUN, MK dan juga untuk mencabut kembali keputusan tersebut oleh Jaksa Agung.

\section{Aspek-Aspek Dalam Penetapan Pengesampingan Perkara oleh Jaksa Agung}

Dengan melihat kewenangan pengesampingan perkara tersebut dalam penegakan hukum di Indonesia, maka diperlukan suatu pelaksanaan yang bersifat objektif, proporsional, dan transparan. Isu yang terus bermunculan terkait dengan seponering yang dilaksanakan oleh Jaksa Agung akan selalu menimbulkan perdebatan mengingat tidak adanya parameter yang jelas terkait kepentingan umum. Sekaligus juga tidak ada prosedur dan mekanisme yang jelas dalam pengesampingan perkara itu sendiri. Oleh karena itu, penulis memberikan pandangan terkait beberapa aspek penting dalam penetapan pengesampingan perkara demi kepentingan umum, sebagai berikut:

1. Ruang lingkup dan indikator kepentingan umum

Menyadari bahwa elemen terpenting dalam pengesampingan perkara ialah aspek kepentingan umum perkara tersebut. Namun diakui, luasnya ruang lingkup kepentingan umum ini menjadikan idealitas pengkonstruksian elemen tersebut menjadi tidak mudah. Di sisi lain dalam menganalisis dan menilai kategori kepentingan umum tidak dapat dapat diserahkan begitu saja oleh aparat penegak hukum yakni kejaksaan karena akan menghilangkan objektivitas kepentingan umum itu sendiri. Dalam penjelasan bab sebelumnya bahwa salah satu pertimbangan dalam menilai kepentingan umum dapat melalui landasan konstitusional itu sendiri. Pembukaan UUD 1945 dan pasal-pasal dalam UUD 1945 merupakan manifestasi dari cita-cita negara hukum yang berusaha untuk melindungi kepentingan umum yakni kepentingan negara dan kepentingan masyarakat luas.

Dalam menilai kepentingan umum yakni kepentingan negara dan masyarakat luas tersebut juga harus dilihat secara objektif. Bahwa kepentingan umum dipertimbangkan melalui besarnya potensi dampak negatif yang dapat ditimbulkan dari penuntutan perkara pidana. Dampak negatif yang dapat ditimbulkan tersebut terhadap pertahanan dan keamanan negara, ketertiban masyarakat luas, dan keberlanjutan kehidupan bersama yang kondusif. Sehingga 
pejabat negara harus memutuskan melalui kewenangan seponering tersebut untuk tidak melakukan penuntutan.

Salah satu undang-undang yang dapat menjadi rujukan terkait kepentingan umum ialah Undang-undang Nomor 30 Tahun 2014 tentang Administrasi Pemerintahan. Pasal 23 menyatakan:

"Diskresi Pejabat Pemerintahan meliputi :.... D. pengambilan Keputusan dan/atau tindakan karena adanya stagnansi pemerintahan guna kepentingan yang lebih luas.”

Dalam penjelasan pasal 23 tersebut menyatakan :

"Yang dimaksud dengan "kepentingan yang lebih luas" adalah kepentingan yang menyangkut hajat hidup orang banyak, penyelamatan kemanusiaan dan keutuhan negara, antara lain: bencana alam, wabahpenyakit, konflik sosial, kerusuhan, pertahanan dan kesatuan bangsa."

Pasal tersebut dapat menjadi rujukan bagi Undang-Undang Kejaksaan dalam menjelaskan kepentingan umum itu sendiri. Kepentingan umum harus dijelaskan secara rinci dan jelas seperti halnya "kepentingan yang lebih luas" dalam pelaksanaan diskresi. Selanjutnya apabila dibandingkan dengan negara yang menerapkan asas oportunitas secara menyeluruh seperti di Belanda. Maka penerapan penghentian penuntutan dengan alasan kebijaksaan atau beleidsepot dapat dilakukan dengan berbagai pertimbangan. Salah satu pertimbangan beleidsepot tersebut karena adanya kepentingan negara yang hampir sama dengan pengesampingan perkara demi kepentingan umum (Peter J.PTak, 2008;82). Penghentian penuntutan dengan alasan kebijaksaan (beleidsepot) dalam sistem penuntutan di Belanda pada umumnya hampir sama dengan negara-negara lain yang menganut asas oportunitas. Seperti di Inggris dengan lembaga CPS (Crown Prosecution Service) sebagai lembaga penuntutan memiliki kewenangan diskresi yang luas. Adapun sebagai perbandingan penghentian penuntutan dengan alasan kebijakan dapat dilihat pada tabel berikut :

Tabel 1. Penerapan Penghentian Penuntutan dengan Alasan Kebijakan di Inggris dan Belanda

\begin{tabular}{|c|c|c|}
\hline Perihal & Inggris & Belanda \\
\hline Jenis & $\begin{array}{l}\text { Public Interest Ground yang } \\
\text { merupakan tahapan dimana } \\
\text { penuntut umum dapat } \\
\text { mempertimbangkan untuk tidak } \\
\text { melakukan penuntutan dengan } \\
\text { alasan kebijakan. Penuntut umum } \\
\text { hanya bisa sampai ke tahap ini } \\
\text { setelah melalui tahap Evidential } \\
\text { Ground }\end{array}$ & $\begin{array}{l}\text { Beleidsepot atau penghentian } \\
\text { penuntutan dengan alasan kebijakan. } \\
\text { Diterapkan dengan dengan bersyarat } \\
\text { atau tanpa syarat }\end{array}$ \\
\hline Syarat & $\begin{array}{l}\text { - Pengadilan kemungkinan } \\
\text { memberikan hukuman denda; } \\
\text { - Usia tersangka terlalu muda } \\
\text { atau terlalu tua; } \\
\text { - Tindak pidana terjadi karena } \\
\text { kesalahpahaman } \\
\text { - Kejahatan bersifat ringan } \\
\text { - Pelaku memiliki peran kecil } \\
\text { dalam tindak pidana }\end{array}$ & $\begin{array}{l}\text { - Kejahatannya merupakan kejahatan } \\
\text { ringan; } \\
\text { - Keterlibatan tersangka dalam tindak } \\
\text { pidana tergolong kecil; } \\
\text { - Usia tersangka terlalu muda atau } \\
\text { terlalu tua; } \\
\text { - Tersangka pada saat itu telah } \\
\text { dihukum untuk tindak pidana lain; }\end{array}$ \\
\hline
\end{tabular}


- Penuntutan akan berdampak pada kesehatan fisik dan mental pelaku

- Tersangka membayar kerugian atau kompensasi dari kejahatan yang dilakukan

- Penuntutan akan berdampak pada keamanan negara dan hubungan internasional
- Kejahatan yang terjadi telah memberikan dampak negative terhadap tersangka sendiri (yakni tersangka menjadi korban atas

kejahatan yang dilakukannya);

- Kondisi kesehatan tersangka;

- Penuntutan akan bertentangan dengan kepentingan negara (misal keamanan negara, perdamaian dan ketertiban);

- Tersangka telah membayar kompensasi.

Mekanisme penghentian penuntutan dengan alasan kebijaksaan ini juga diadopsi dalam Rancangan Undang-Undang KUHAP. Dimana mekanisme penghentian penuntutan dengan adanya beberapa pertimbangan yang salah satunya juga adanya kepentingan umum. Untuk memberikan gambaran, dapat dilihat perbedaan pengesampingan pekara dalam UU Nomor 16 Tahun 2004 dan penghentian penuntutan demi kepentingan umum dalam RUU KUHAP dalam tabel berikut :

Tabel 1 Perbedaan pengesampingan pekara dalam UU Nomor 16 Tahun 2004 dan penghentian penuntutan demi kepentingan umum dalam RUU KUHAP 2013

\section{Undang-Undang Nomor $16 \quad$ RUU KUHAP 2013}

Tahun 2004

Pasal 35 huruf c Undang-Undang Pasal 42 ayat 2 RUU KUHAP

Nomor 16 Tahun 2004

Jaksa Agung $\quad$ Penuntut Umum

Mengesampingkan perkara demi Menghentikan penuntutan demi kepentingan umum kepentingan umum dan/atau alasan tertentu

Adanya kepentingan umum, yakni kepentingan bangsa, dan negara dan/atau masyarakat luas.
Adanya kepentingan umum dan/atau alasan tertentu. Kewenangan tersebut dapat dilaksananakan jika :

a. tindak pidana yang dilakukan bersifat ringan;

b. tindak pidana yang dilakukan diancam dengan pidana penjara paling lama 4 (empat tahun);

c. tindak pidana yang dilakukan hanya diancam dengan pidana denda;

d. umur tersangka pada waktu melakukan tindak pidana di atas 70 (tujuh puluh) tahun; dan/atau 
e. kerugian sudah diganti.

Tidak terdapat pertanggungjawaban

Dalam hal penuntut umum menghentikan penuntutan sebagaimana dimaksud pada ayat (2), penuntut umum wajib menyampaikan laporan pertanggungjawaban kepada kepala kejaksaan tinggi setempat melalui kepala kejaksaan negeri setiap bulan.

Apabila ditinjau dari mekanisme beleidsepot di Belanda dan juga penghentian penuntutan demi kepentingan umum dalam RUU KUHAP. Terdapat salah satu pertimbangan dimana kewenangan untuk tidak melakukan penuntutan yakni kejahatan atau tindak pidana bersifat ringan. Tentunya hal ini baik dengan melihat realitas hukum saat ini. Seperti halnya kasus nenek minah yang mencuri tiga buah kakao dan dihukum 1 bulan dengan masa percobaan 3 bulan. Apabila dilihat dari skala kesalahannya dan kerugian kepada korban tentu perkara ini tidak layak untuk dilimpahkan ke pengadilan. Bahkan perkara-perkara kecil dapat dikatakan dapat mengganggu kepentingan umum karena menghilangkan proporsionalitas keadilan dalam penegakan hukum. Selanjutnya sangat diperlukan agar penjelasan kepentingan umum dijelaskan secara rinci agar kewenangan tersebut dapat menghadirkan rasa kepastian hukum.

2. Badan kekuasaan negara dalam penetapan pengesampingan perkara

Sesuai dengan penjelasan pasal 35 huruf c Undang-Undang Nomor 16 Tahun 2004 bahwa Jaksa Agung harus memperhatikan saran dan pendapat badan kekuasaan negara dalam memberikan penetapan pengesampingan perkara. Adapun penjelasan pasal tersebut yakni :

“...Mengesampingkan perkara sebagaimana dimaksud dalam ketentuan inimerupakan pelaksanaan asas oportunitas, yang hanya dapat dilakukanoleh Jaksa Agung setelah memperhatikan saran dan pendapat dari badan-badan kekuasaan negara yang mempunyai hubungan denganmasalah tersebut."

Uraian penjelasan pasal tersebut menunjukkan bahwa kewenangan Jaksa Agung dalam mengesampingkan perkara harus juga mempertimbangkan saran dari badan kekuasaan negara. Apabila hal ini dapat berjalan sesuai penjelasan pasal tersebut maka akan menjadi mekanisme dalam membatasi dan mengawasi kewenangan Jaksa Agung. Akan tetapi, belum terdapat penjelasan yang spesifik terkait badan-badan kekuasaan negara tersebut. Hal ini menunjukkan banyak ketidakjelasan dalam penjelasan pasal 35 huruf c sehingga tidak memberikan kepastian hukum dalam penerapannya.

Apabila merujuk pada kajian tentang kekuasaan negara dapat dilihat pada teori kekuasaannegaraBaron de Montesquieu yang dikenal dengan Trias Politica. Kekuasaankekuasaan negara dipisahkan menjadi kekuasaan eksekutif yakni kekuasaan pelaksana undang-undang, kekuasaan legislatif yakni kekuasaan pembuat undang-undang, dan kekuasaan yudikatif yakni kekuasaan mengadilii. Beranjak dari pandangan tersebut maka badan-badan kekuasaan negara sesuai penjelasan pasal tersebut ialah lembaga atau badan 
negara yang bertugas menjalankan kekuasaan eksekutif, legisltatif, dan yudikatif. Dihubungkan dengan prinsip pembagian kekuasaan negarasesuai dengan mandat UndangUndang Negara Republik Indonesia Tahun 1945 dalam UUD 1945 beserta perubahannya, maka yang dimaksud'badan-badan kekuasaan negara' adalah lembaga-lembaga negara yangwewenangnya meliputi kekuasaan-kekuasaan negara yakni kekuasaan eksekutif yaitu Presiden dan Wakil Presiden, kekuasaan legislatif yaitu DPR dan DPD, kekuasaan yudikatif yaitu Mahkamah Agung dan Mahkamah Konstitusi.

Pengunaan istilah 'badan-badan kekuasaan negara' dalam wewenang Jaksa Agung mengesampingkan perkara demikepentingan umum kurang tepat, karena membatasi Jaksa Agung dalam memilih lembaga negara apa “...yang mempunyai hubungan dengan masalah tersebut” sebagaimana dinyatakan dalam penjelasan Pasal 35 huruf c UU No. 16 Tahun2oo4 tentang Kejaksaan Republik Indonesia. Sebaiknya istilah 'badan-badankekuasaan negara' tersebut diganti dengan istilah 'lembaga negara' saja,karenawewenang Jaksa Agung mengesampingkan perkara demi kepentingan umum diterapkan dalam rangka menjalankan kekuasaan eksekutif di bidang penegakan hukum pada tahap penuntutan, dimana menurut penulis tidak dapat diprediksikanperkara apa yang akan dikesampingkan di masa mendatang, yang akan mempunyai konsekuensi kepada 'lembaga negara' mana yang mempunyaihubungan dengan masalah dalam perkara tersebut yang harus diperhatikan saran dan pendapatnya oleh Jaksa Agung. Istilah 'lembaga negara' menurut penulis lebih tepat digunakan karena cakupannya lebih luas dari pada 'badan-badan kekuasaan negara'. Di dalam istilah lembaga Negara terdapat 2 (dua) unsur pokok yang saling berkaitan, yaitu organ dan fungsi.

\section{Mekanisme dan prosedur dalam pengesampingan perkara}

Mengingat dampak atau implikasi dalam penetapan seponering akan berdampak pada banyak pihak, maka mekanisme dan prosedur harus ditetapkan. Seperti dijelaskan sebelumnya bahwa penetapan pengesampingan perkara harus dilaksanakan dengan memperhatikan saran dan pendapat badan kekuasaan negara. Akan tetapi dalam perundang-undangan tidak dijelaskan secara rinci yang dimaksud dengan badan kekuasaan negara tersebut. Dengan memperhatikan standar prosedural itu maka diharapkan penetapan pengesampingan perkara dapat dilakukan dengan prinsip objektivitas dan keterbukaan.

Lebih lanjut prosedur penetapan tersebut tidak dapat berjalan secara maksimal mengingat Jaksa Agung hanya diwajibkan untuk memperhatikan saran dan pendapat badan kekuasaan negara. Hal ini diterapkan dalam penetapan pengesampingan perkara Abraham Samad dan Bambang Widjojanto, dimana Jaksa Agung meminta pendapat dari DPR. Adapun DPR dalam hal ini komisi III melalui Wakil Ketua Komisi III Desmond Mahesa memberikan komentar bahwa:

"Komisi III menilai tak ada alasan kepentingan bagi kejaksaan untuk mengesampingkan kasus Abraham dan Bambang. Sebab, keduanya tak lagi menjabat sebagai pimpinan KPK. Hal ini berbeda dengan kasus Chandra-Bibit yang masih menjabat sebagai pimpinan sehingga memiliki unsur kepentingan umum".

Akan tetapi pendapat tersebut tidak memiliki kedudukan memaksa dan mengikat keputusan Jaksa Agung. Jaksa Agung hanya diharuskan untuk memperhatikan saran dan pendapat dari badan kekuasaan negara. Oleh karenanya, dalam pembentukan perundang-undangan yang mengatur pengesampingan perkara ini. Diperlukan mekanisme atau prosedur yang jelas termasuk juga status yang mengikat dari pendapat badan kekuasaan negara. Sehingga dengan 
berlakunya hal ini penetapan pengesampingan perkara tidak hanya terpaku oleh pendapat Jaksa Agung yang cenderung subjektif. Keterlibatan pandangan dan pendapat dari stakeholders negara lainnya dalam penetapan tersebut dapat memberikan keterbukaan, objektivitas, dan tranparansi. Hal ini dapat membantu dalam mewujudkan kepastian hukum dan menghindari penyalahgunaan wewenang.

\section{KESIMPULAN}

Kepentingan umum dalam pengesampingan perkara merupakan hasil pertimbangan berbagai kepentingan dengan tujuan untuk memberikan kemanfaatan kepada masyaarakat luas. Tercermin dalam perkara-perkara yang telah dikesampingkan oleh Jaksa Agung dengan masing-masing pertimbangannya maka secara kasuistik dapat dianalisa beberapa kriteria kepentingan umum, yakni menjaga keamanan dan ketertiban negara, mewujudkan stabilitas politik pemerintahan, menghindari terjadinya konflik sosial, memperhatikan kesejahteraan rakyat, dan mendukung upaya pemberantasan korupsi (Bima, Kamal \& Djanggih, 2019). Pengesampingan perkara demi kepentingan umum terhadap Abraham Samad dan Bambang Widjojanto dengan pertimbangan Jaksa Agung terkait aspek filosofis dan yuridis. Setelah dianalisis lebih lanjut terkait pertimbangan Jaksa Agung tersebut, maka keputusan untuk mengesampingkan perkara terhadap Abraham Samad dan Bambang Widjojanto belum menunjukkan terganggunya kepentingan umum secara nyata yakni kepentingan negara dan/atau kepentingan masyarakat luas.

\section{SARAN}

1. Diperlukan adanya revisi terhadap Undang-Undang Nomor 16 Tahun 2004 Tentang Kejaksaan yang memberikan kewenangan mengesampingkan perkara demi kepentingan umum oleh Jaksa Agung. Perbaikan ini tentunya dalam penjelasan pasal 35 huruf c terkait frasa "kepentingan umum" yang belum memenuhi asas lex certa (clarity principle). Hal ini dibutuhkan untuk mewujudkan kepastian hukum dan tidak bersifat multi tafsir dalam pasal tersebut.

2. Diperlukan penjelasan lebih spesifik terkait frasa kepentingan umum yakni kepentingan bangsa dan kepentingan negara dan/atau kepentingan masyarakat luas. Bentuk penjelasan pasal tersebut juga dapat dilakukan dengan memberikan kriteria atau indikator dari kepentingan umum agar dapat menjadi pedoman atau tolak ukur bagi Jaksa Agung dalam menggunakan kewenangannya.. Dalam pelaksanaan keputusan pengesampingan perkara tersebut selain klausula "kepentingan umum" yang harus diperhatikan dan dijelaskan lebih spesifik dalam pembentukan perundang-undangan selanjutnya..Keputusan seponering sebaiknya tidak hanya berdasarkan pertimbangan subjektif Jaksa Agung saja dalam menilai adanya kepentingan umum. Saran dan pendapat "badan kekuasaan negara" memiliki kedudukan yang mengikat dalam keputusan pengesampingan perkara demi kepentingan umum. Hal ini juga sebagai mekanisme penilai pertimbangan Jaksa Agung terkait adanya kepentingan umum, sekaligus sebagai mekanisme pengawas bagi kewenangan subjektif tersebut. 


\section{DAFTAR PUSTAKA}

Aditiawarman, A. (2017). Kedudukan Deponering Sebagai Manifestasi Asas Oportunitas Dalam Perkara Pidana (Doctoral dissertation, Universitas Andalas).

Basalama, F. A. (2017). Eksistensi Asas Legalitas dalam Undang-undang Nomor 8 Tahun 1981 Tentang Kitab Undang-undang Hukum Acara Pidana. Lex Crimen, 6(5), 25-27

Bima, M. R., Kamal, M., \& Djanggih, H. (2019). Legitimasi Hak Angket Dewan Perwakilan Rakyat Terhadap Komisi Pemberantasan Korupsi. Jurnal Kertha Patrika, 41(1), 27-39.

Chalil, S. M. (2016). Pengesampingan Perkara (Deponering) oleh Jaksa Agung. Wacana Paramarta: Jurnal Ilmu Hukum, 15(1), 1-10.

Hisamudin, A. (2016). Penerapan Asas Oportunitas dalam Perkara Pidana Bambang Widjojanto Dihubungkan dengan Tujuan Hukum Tentang Kemanfaatan (Doctoral dissertation, Fakultas Hukum Universitas Pasundan).

Iqbal, M. (2018). Implementasi Efektifitas Asas Oportunitas di Indonesia Dengan Landasan Kepentingan Umum. Jurnal Surya Kencana Satu: Dinamika Masalah Hukum dan Keadilan, 9(1), 87-100.

Marom, M. N., \& Suyanto, S. (2020). Akibat Hukum Penyampingan Perkara Pidana Demi Kepentingan Umum Oleh Kejaksaan Agung (Deponering). Jurnal Pro Hukum: Jurnal Penelitian Bidang Hukum Universitas Gresik, 8(2), 173-190.

Nugraha, Y. (2020). Optimalisasi Asas Oportunitas Pada Kewenangan Jaksa Guna Meminimalisir Dampak Primum Remedium Dalam Pemidanaan. Veritas et Justitia, 6(1), 213-236.

Rahman, T. (2010). Dasar Teori Kewenangan Penyidik Maupun Penuntut Umum dalam Menghentikan Perkara Pidana. Yuridika, 25(1), 13-32.

Suhariyanto, B. (2015). Pelenturan hukum dalam putusan peninjauan kembali yang diajukan oleh jaksa penuntut umum. Jurnal Yudisial, 8(2), 191-207.

Utoyo, M. (2016). Kewenangan Deponering Dalam Sistem Peradilan Pidana Indonesia. Doctrinal, 1(2), 229-244.

Yudha, G. (2020). Lembaga Deponering Sebagai Implementasi Asas Oportunitas Perkara Pidana Di Indonesia. UNES Law Review, 2(3), 331-345.

Yuherawan, D. (2012). Kritik Ideologis Terhadap Dasar Kefilsafatan Asas Legalitas Dalam Hukum Pidana. Jurnal Dinamika Hukum, 12(2), 221-235. 